In conclusion I must draw attention to the excellent opportunities which many of those residing in Britain have for the observation of artificially produced earth tremors. By these I mean the vibrations which are produced by our railway trains, our carriages, explosions at mines and quarries, steam hammers, the falling of balls used in the breaking of castings, and other means. All of these vibrations I can state with confidence are capable of being graphically recorded, and the value of a series of such records to the practical seismologist it is hardly necessary to dilate upon.

Investigations of this description are the laboratory work of the practical seismologist, and often lead to more valuable results than those which are obtained from actual earthquakes. Actual earthquakes are produced by unknown causes, they come at unknown times, and from unknown localities. With artificially produced disturbances none of these difficulties have to be contended with, the cause and the result are before us simultaneously, and we are enabled to arrive at laws which actual earthquakes would never yield to us.

Another point to which I should like to draw attention is the study of earth movements in general. Hitherto we have only devoted our attention to the sudden and violent movements which we call earthquakes. In addition to these we have in nature movements of less amplitude called earth tremors. Inasmuch as we now know that these are probably a universal phenomenon, and at the same time are in every probability governed by laws simpler than those which govern earthquakes which are usually due to a complexity of causes, it certainly devolves upon us to establish the necessary means for their investigation. From the little we have learnt about earth tremors it is not unlikely that they may be to our continents what tides are to our oceans, phenomena which are regular and law abiding, and not like the earthquakes, which may be compared to the storms of the ocean.

In addition to these motions of small amplitude we have many reasons for believing in the existence of motions of our ground of great amplitude, but so slow in period that hitherto they have been overlooked.

In order to complete the study of earth motions we have to add to seismology the study of earth tremors and what might be called earth pulsations.

As we have done so much for our skies, for our atmosphere, and for our waters, we can surely do a little towards the investigation of the movements of the earth on which we live.

Although these latter remarks have no direct connection with the work which has been accomplished in Japan, they are nevertheless an outcome of such work, and if they tend in any way to draw attention to a much neglected study, an object will have been attained greater than any which could be hoped for by diffusing a knowledge of the labours of those who dwell at our Antipodes. JOHN MILNE

\section{THE LATE PROFESSOR BALFOUR}

THE meeting held last Saturday to establish a memorial to the late Prof. Balfour was very largely attended by all grades in the University, and among nonresidents by Professors Huxley, H. J. S. Smith, A. W. Williamson, W. K. Parker, Ray Lankester, H. N. Moseley, and A. M. Marshall and Mr. George Griffith, of Harrow. The president of the Royal Society would have boen present but for bis recent accident. The speakers, including most of those mentioned above, and Professors Paget, Humphry, Newton, and Westcott, bore unanimous testimony to the high regard and affection in which the lamented professor was held, to the original work he had accomplished, and the high promise of his life, and to the energy and success of his teaching. Dr. Paget referred to Balfour's having abandoned his favourite pastime of deer-stalking in order not to inflict unnecessary suffering upon harmless animals, and his having taken up instead that of Alpine climbing, in which he met his death. Any memorial to him would, he hoped, do something to perpetuate the spirit in which his scientific achievements had been accomplished, which placed him beside such men as Miller, Sedgwick, and Clerk Maxwell. Mr. A. Sedgwick, late demonstrator with Balfour, spoke of the growth of the class in seven years from ten to ninety students, and of the crushing nature of his loss to the school he had attracted around him, for his personal intercourse and counsel was of the extremest value.

Prof. Huxley, in proposing "That the memorial take the form of a fund, to be called the Balfour Fund, for the promotion of research in biology, especially animal morphology," said that after the addresses they had listened to with painful interest, it would be superfluous for him to add his personal testimony to the remarkable sagacity and the remarkable characteristics of Prof. Balfour. It was no exaggeration to say that in his eyes and to many of his age he seemed to be like Lycidas, of whom Milton wrote, "who died in his prime and hath not left his peer." The remarkable capacity he exhibited was developed by a multitude of surrounding circumstances. $\mathrm{He}$ was happy to say that he personally had contributed, amid a multitude of more powerful forces, to that which led to the development of his great powers. When Balfour was a young man, a paper he had written while at Harrow School was sent to him for his judgment, and again when Balfour was a candidate for a Fell'swship at Trinity College, he was one of the examiners. "Amid many of my faults and failings during a long life," said Prof. Huxley, "I do not reproach myself for neglecting to recognise the capacity of the friend we have lost, both in the paper written while at Harrow and during the examination for the Fellowship at Trinity." $\mathrm{He}$ would draw attention to two words in the resolution he proposed-viz., research and morphology. The late Professor distinguished himself in both these directions. In former days men were content with being learned, but now we must not only know what is known, but help to extend the bounds of knowledge. This Balfour did. and his title as an eminent researcher was undoubted. With regard to morphology, it was a science until recently only known as a field of wide speculation of German philosophers. It was now a new learning, a great system of doctrine, established by an enormous mass of carefully co-ordinated facts. Three things were requisite to develop this new science:-I. Mastery of practical methods. 2. Accuracy of observation. 3. Vividness of imagination. He had never met any one more marvellously gifted with these three great qualities than Prof. Balfour. If his unshrinking modesty could have foretold this meeting, there would not be any form of memorial more entirely grateful to his feelings than the one proposed. A monument in stone or brass would be inappropriate; but to establish through this fund a perennial spring of activity in the direction of the study he pursued would be a more lasting and perfect memorial. And they might think of him in the consluding words of "Lycidas":- "Henceforth thou art the genius of the shore, In thy large recom pense, and shalt be good To all that wander in that perilous flood"

Prof. Newton proposed "That the proceeds of the fund be applied (I) to establish a studentship, the holder of which shall devote himself to original research in biology, especially animal morphology ; (2) to further, by occasional grants of money, original research in the same subject." He said that the room and the building in which they were assembled reminded him that he felt and entered for the first time into the full meaning of the Poet Laureate's words- "But O! for the touch of a vanish'd hand And the sound of a voice that is still." With refer- 
ence to an allusion of Mr. Sedgwick, he said he should always consider it to be one of the brightest episodes of his career that, having found in Balfour a young man capable of giving instruction, he had afforded him facilities. The late Professor was not only an instructor but a student, and no one ever remained so much a student."

Prof. Williamson proposed "That a committee be appointed to collect subscriptions and to draw up conditions under which, with the sanction of the subscribers at a future meeting, the fund shall be offered to the University."

Dr. Michael Foster proposed the following resolution:"That the Committee be instructed-(I) that the value of the studentship be not less than $200 \%$. a year; (2) that while it is desirable that the studentsbip should be in some way closely connected with this University, persons other than members of this University shall be eligible to it; (3) that it be not given away by competitive examination; (4) that in framing regulations both for the conduct of the student and the award of occasional grants, the primary object of the fund-namely, the furtherance of original research, be closely adhered to." $\mathrm{He}$ said he thought the above instructions to the Committee did not need any defence. The object of the memorial was not to keep Prof. Balfour's memory alive, for his works would do that, but to connect his name with some useful thing. The idea in fixing the value of the studentship at $200 \%$ was that such a sum would be just sufficient to attract men led by enthusiasm to turn their attention to research, while it would be insufficient to induce persons to accept it as a competency. He thought it right not to restrict the studentship to members of the University, for they desired to attract talent from all parts of the country, while he considered that it was a proper condition not to throw it open to a competitive examination, for the studentship was not intended as a reward for past work or an acknowledgment of merit, but to encourage men of promise to undertake research.

An influential committee was appointed to collect subscriptions and draw up detailed conditions under which, after a future meeting of subscribers, the fund may be offered to the University. Mr. J. W. Clark, M.A., I, Scroop Terrace, and Mr. A. Sedgwick, M.A.; Trinity College, Cambridge, were appointed secretaries of the committee, the former to act as treasurer. The fund starts well, with the munificent contribution of 3000 l. from the family of the late Prof. Balfour, and to roool. which had been left by the deceased to Dr. Michael Foster to be applied according to his discretion for the promotion of biology; nearly 10ool. was subscribed in the room or shortly afterwards.

\section{DR. THWAITES}

GEORGE HENRY KENDRICK THWAITES, whose death was recorded in a recent number of NATURE, was a well-known member of the older generation of British botanists. I do not know the exact date or place of his birth, but suppose it to have been in $18 \mathrm{II}$. In his early life he followed the profession of Notary Public at Bristol, and apparently had a hard struggle to support and educate numerous younger brothers and sisters. He had a natural passion for botanical studies which he cultivated to such good purpose as to obtain the appointment of Lecturer on Botany and Vegetable Physiology at the School of Medicine at Bristol. $\mathrm{He}$ was no less ardent as an entomologist, and throughout his life collected assiduously; some of his earliest papers are on entomological subjects. His principal published work has, however, always been botanical. Till he left England he was mostly occupied with microscopical investigations, and what he published of these were like all that he did later-excellent specimens of careful and intelligent observation. His paper "On the Cell-membrane of plants" (1846) which established many inter- esting and at that time novel points, received a good deal of attention. Amongst other things it apparently gave the first accurate interpretation of the mucous investment of the cells of many Palmellea, Nostochinea, and Diatomacece; Thwaites was able to show clearly that this was the product of the gelatinisation of the cell-walls. His capital discovery, however, was that of Conjugation in the Diatomacee. This he observed in Eunotia turgida, and the paper describing it bears the date May I I, I847, and was published in the Annals and Magazine of Natural History. It was, as Thwaites himself remarked, "a discovery which is valuable as proving that a relationship of affinity as well as of analogy exists between the Diatomacear and the Desmidece and Conjugate, and will help to settle the question as to whether the former are to be referred to the animal or the vegetable kingdom." I have been told nevertheless that when this important discovery was communicated to the British Association at Oxford, it was received with but little attention.

The present director of the Royal Gardens, Kew, then Dr. Hooker, was about this time attached to the Geological Survey. At the instance of Sir Henry de la Bêche he was engaged in the Bristol Coal Field, endeavouring to ascertain whether any definite relation could be traced between the superficial flora and the underlying rocks. Tt "s brought him in contact with Dr. Thwaites, who was, notwithstanding his professional pursuits, in the habit of spending the early hours of the morning in teaching himself the practical details of gardening in the Durdham Down nurseries. It was probably this circumstance which brought under his notice the curious instance of hybridity in a Fuchsia, which so much excited the interest of Mr. Darwin, and has often been referred to. A seed of $F$. coccinea fertilised by $F$. fulgens contained two embryos. These were extremely different in appearance and character, though both resembled other hybrids of the same parentage produced at the same time. What was still more remarkable, was that they were closely coherent below the two pairs of cotyledon-leaves into a single cylindrical stem.

In I 847 Thwaites was an unsuccessful candidate for a chair of botany in one of the newly founded Queen's Colleges in Ireland. His combined scientific and practical knowledge, however, indicated his fitness for a botanical post, and on the death of Dr. Gardner, he was appointed in June, I849, Director of the Royal Botanic Garden, Peradeniya, Ceylon, on the recommendation of Sir William Hooker. He never returned to this country, and from the first threw himself into the duties of his post with great fervour; under his management Peradeniya became perhaps the most beautiful tropical garden in the world. He continued the labours of his predecessors in investigating the very peculiar flora of the island with great success, and, between the years $1858-64$, issued, in parts, the "Enumeratio plantarum Zeylaniæ." This was at the time of its publication the first complete account on modern lines of any definitely-circumscribed tropical flora. The want of affinity which the flora thus worked out was seen to have to the general vegetation of the contiguous peninsula of Hindostan and its marked relationship to that of the Malayan region established facts of the greatest significance in the study of geographical distribution. A passage from the preface (1864) is worth quoting, as showing that Thwaites was one of the earliest English naturalists to give his adhesion to the Darwinian theory :-

"These forms or varieties would probably be viewed by some botanists in the light of distinct, though closelyallied species, and they occupy, in fact, that debatable ground the difficulties and perplexities of which the practical naturalist alone knows, and which in the opinion of many (and I may include myself amongst the number) are only to be got rid of by the adoption of the views enunciated by Mr. Darwin as regards the relationship of 